\title{
PENGARUH BOOK TAX DIFFERENCES DAN TINGKAT UTANG TERHADAP PERSISTENSI LABA \\ (Studi Empiris Pada Perusahaan Sektor Property dan Real Estate yang terdaftar di Bursa Efek Indonesia tahun 2016-2018)
}

\author{
Jessica Putri Diharjo ${ }^{1}$ \\ ${ }^{1}$ Fakultas Ekonomi Universitas Krisnadwipayana \\ Jalan Unkris Jatiwaringin Jakarta Timur \\ Email: jessicaputridiharjo97@gmail.com \\ Mishelei Loen ${ }^{2}$ \\ ${ }^{2}$ Fakultas Ekonomi Universitas Krisnadwipayana \\ Jalan Unkris Jatiwaringin Jakarta Timur \\ Email: mishelei.loen@gmail.com
}

\begin{abstract}
Earnings persistence is one of the estimated value of earnings and an element of earnings relevance. The purpose of this research is to determining the effect of variable book tax differences, and leverage either simultaneously or partially to the variable earning persistence. Book tax differences variable is proxied with temporary differences and permanent differences in fiscal reconciliation. Populations used in this study is property and real estate sector companies listed on the Indonesia Stock Exchange 2016-2018, were entered as the population was registered are 70 companies, then obtained a sample of 18 companies. The sampling technique used was purposive sampling technique in which the number of observations obtained this study was 41. Data analysis conducted with multiple regression model with help of software SPSS version 25. Based on the results of this research showed a combination of two variables (book tax differences is proxied with temporary differences and permanent differences, and leverage) can affect the earning persistence 35\%, while the rest influenced by other variables outside the research. The results also showed simultaneously Book tax differences variable is proxied with temporary differences and permanent differences an leverage significant effect on earnings persistence. From the partial test results showed that the variables Book tax differences variable is proxied with permanent differences and leverage positive significant effect on earning persistence. Variable Book tax differences variable is proxied with temporary differences did not have any affect on Earnings Persistence.
\end{abstract}

Keywords: Book Tax Differences; Temporary Differences; Permanent Differences; Leverage, and Earnings Persistence

\section{PENDAHULUAN}

Salah satu faktor yang dapat mengukur keberhasilan suatu entitas adalah laba. Dengan laba, perusahaan dapat menjaga kelangsungan bisnis dan melakukan berbagai pengembangan demi kemajuan bisnis dan untuk mendapatkan keuntungan. Laba adalah kelebihan penghasilan diatas biaya selama satu periode akuntansi (Harahap 2009). Salah satu masalah sulit dalam mengukur pencapaian atau keberhasilan suatu entitas adalah pengukuran laba.

Persistensi laba akuntansi adalah revisi dalam laba akuntansi yang diharapkan di masa depan (expected future earnings) yang diimplikasi oleh laba akuntansi tahun berjalan (Djamaluddin et al. 2008). Persistensi laba dapat mempertahankan laba perusahaan dari waktu ke waktu, dengan harapan dapat menunjukkan prediksi dimasa mendatang. Persistensi laba yang sustainable dinyatakan sebagai laba yang mempunyai kualitas tinggi 
sebaliknya jika laba unusual dinyatakan sebagai laba yang mempunyai kualitas jelek (Penman Stephen H. \& Xiao- Jun Zhang 2002). Menurut Moienadin (2014) berpendapat bahwa laba akuntansi, dianggap sebagai sumber informasi yang paling signifikan untuk mengevaluasi profitabilitas masa depan.

Selain itu, penyebab dari persistensi laba (pendapatan masa depan) menurut masalah yang ada saat ini di Indonesia adalah karena perbedaan antara laba akuntansi menurut standar akuntansi keuangan dan pendapatan pajak atau sering disebut laba fiskal sesuai dengan peraturan perpajakan. Berawal dari hal tersebut kemudian muncul istilah laporan keuangan komersial dan laporan keuangan fiskal. Adanya 2 jenis laba menyebabkan terjadi perbedaan antara laba akuntansi dengan laba fiskal. Hal ini terjadi karena, peraturan perpajakan dan peraturan akuntansi mempunyai tujuan, dasar penyusunan dan kepentingan yang berbeda masing-masing diantara para pengguna informasi laba tersebut, sehingga perbedaan tersebut hampir muncul disemua negara (Persada \& martani 2010). Book-tax differences dalam analisis perpajakan dapat menjadi salah satu cara untuk menilai kualitas laba suatu entitas. Karena, book tax differences berkaitan dengan informasi laba sehingga dapat digunakan untuk mengevaluasi kinerja perusahaan. Namun, manfaat book tax differences tersebut tidak selalu timbul akibat adanya praktik manajemen laba yang dilakukan perusahaan. Adanya bukti mengenai kegunaan book tax differences dalam kaitannya dengan informasi laba menjadikan informasi book tax differences menjadi penting untuk dipahami dan dibahas. $\begin{array}{lcr}\text { Tingkat } & \text { utang } & \text { merupakan } \\ \text { kemampuan } & \text { perusahaan } & \text { untuk } \\ \text { membayar } & \text { kewajiban } & \text { jangka }\end{array}$ panjangnya. (Fanani 2010) menyatakan bahwa tingginya tingkat utang perusahaan biasanya dipengaruhi oleh hutang jangka panjang. Menggunakan utang yang cukup tinggi dalam bisnis akan meningkatkan risiko bisnis. Menggunakan utang yang tinggi akan memberikan insentif yang lebih kuat bagi perusahaan untuk meningkatkan persistensi laba dengan mengelola laba untuk efisiensi. Peningkatan persistensi laba untuk menjaga kinerja yang baik di mata investor dan auditor sehingga kreditor terus memiliki kepercayaan pada perusahaan dan mudah untuk mengucurkan dananya. Semakin besar tingkat utang suatu perusahaan semakin tinggi persistensi laba (Pagalung 2006). Utang juga mempengaruhi persistensi laba dan tingkat stabilitas perusahaan, yang akan berdampak pada kelangsungan hidup perusahaan di masa depan.

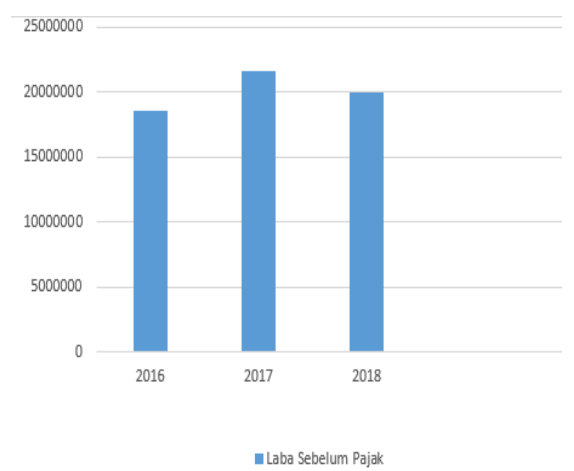

Gambar 1. Laba Sebelum Pajak Pada Perusahaan Sektor Property dan Real Estate tahun 2016-2018 (dalam jutaan rupiah)

Gambar 1 menunjukkan bahwa perkembangan laba sebelum pajak pada perusahaan sektor industri property dan real estate yang terdaftar di BEI tahun 
2016-2018 mengalami fluktuasi. Karena pada tahun 2017 perusahaan sektor property dan real estate mampu mempertahankan labanya dan laba mempunyai kualitas tinggi. Sehingga perusahaan memiliki persistensi laba yang sustainable. Namun pada tahun 2018 perusahaan sektor property dan real estate tidak mampu mempertahankan labanya dan laba mempunyai kualitas yang jelek. Sehingga perusahaan memiliki persistensi laba yang unusual. Jika perusahaan tidak dapat mempertahankan labanya dapat menjadi bahan pertimbangan investor dan kreditor yang menggunakan laporan keuangan untuk pengambilan keputusan investasi. Fenomena fluktuasi laba sebelum pajak perusahaan property dan real estate tersebut menyebabkan persistensi laba pada sektor industri tersebut mulai dipertanyakan, karena laba dengan fluktuasi menurun curam dalam waktu yang singkat menunjukkan perusahaan tersebut tidak mampu untuk mempertahankan laba yang diperoleh saat ini maupun menjamin laba untuk masa depan (Zhou 2016).

Berdasarkan beberapa penelitian sebelumnya, terdapat beberapa perbedaan hasil penelitian pengaruh Book tax differences terhadap persistensi laba adalah penelitian yang (Praptitorini 2017), (Suwandika 2013), (Putri et al. 2017), (Barus \& Rica 2014), menyatakan bahwa book tax differences berpengaruh signifikan terhadap persistensi laba. Sedangkan penelitian yang dilakukan (Salsabila et al. 2016) dan (Septavita 2016) menyatakan bahwa Book tax differences tidak berpengaruh signifikan terhadap persistensi laba. Terdapat beberapa perbedaan hasil penelitian pengaruh Tingkat Utang terhadap persistensi laba adalah penelitian yang dilakukan (Putri et al. 2017), (Putri et al. 2016) dan (Fanani 2010), (Nadya dan Namira 2018), (Barus dan Rica 2014), dan (Kasiono 2016) menyatakan bahwa tingkat utang berpengaruh signifikan terhadap persistensi laba. Sedangkan penelitian yang dilakukan (Suwandika 2013), dan (Praptitorini 2017) menyatakan bahwa tingkat utang tidak berpengaruh signifikan terhadap persistensi laba. Penelitian ini dilakukan untuk menguji kembali hubungan Book Tax Differences dan Tingkat Utang dengan persistensi laba. Adanya ketidakkonsistenan hasil penelitianpenelitian sebelumnya membuat isu ini menarik untuk diteliti kembali. Berdasarkan uraian tersebut diatas maka yang menjadi permasalahan dalam penelitian ini adalah sebagai berikut:

1. Apakah book tax differences berpengaruh terhadap persistensi laba pada perusahaan sektor property dan real estate tahun 2016-2018?

2. Apakah tingkat utang berpengaruh terhadap persistensi laba pada perusahaan sektor property dan real estate tahun 2016-2018?

3. Apakah book tax differences dan tingkat utang berpengaruh terhadap persistensi laba pada perusahaan sektor properti dan real estate tahun 2016-2018?

\section{LANDASAN TEORI}

\section{Perbedaan Laba Akuntansi dengan Laba Fiskal (Book Tax Differences)}

Book tax differences adalah perbedaan besaran laba akuntansi atau laba komersial dengan laba fiskal atau penghasilan kena pajak. Perbedaan laba akuntansi dengan laba fiskal yang timbul akibat standar perhitungan laba yang berbeda antara akuntansi komersial 
dengan perpajakan menyebabkan perusahaan setiap tahunnya melakukan rekonsiliasi fiskal.

\section{Perbedaan Permanen (permanent differences)}

Menurut Pohan (Pohan 2014) Perbedaan tetap adalah Perbedaan pengakuan penghasilan dan biaya dalam menghitung laba menurut standar akuntansi dengan ketentuan perpajakan tanpa koreksi di kemudian hari (sifatnya permanen).

Perbedaan permanen disebabkan oleh pengaturan yang berbeda terkait dengan pengakuan penghasilan dan biaya antara Standar Akuntansi Keuangan dengan Ketentuan Peraturan Perundang-undangan Perpajakan. Jadi dapat dikatakan bahwa berdasarkan ketentuan peraturan perundangundangan perpajakan, ada beberapa penghasilan yang bukan merupakan objek pajak, sedangkan secara komersial penghasilan tersebut diakui sebagai penghasilan.

Perbedaan Permanen dihitung dengan rumus:

Perbedaan Permanen $=$

Jumlah Perbedaan permanen dalam rekonsiliasi fiskal Total Asset

\section{Perbedaan Temporer (Temporary Differences)}

Menurut (Pohan 2014) Perbedaan waktu pengakuan penghasilan dan biaya tertentu dalam menghitung laba menurut akuntansi dengan ketentuan perpajakan. Perbedaan temporer muncul karena adanya perbedaan tujuan antara akuntansi dengan aturan pajak. Perbedaan temporer dapat dibagi menjadi perbedaan waktu positif dan perbedaan waktu negatif.

Perbedaan Temporer dihitung dengan rumus:

$$
\begin{aligned}
& \begin{array}{c}
\text { Perbedaan Temporer } \\
\text { Jumlah Perbedaan Temporer dalam rekonsiliasi fiskal }
\end{array} \\
& \frac{\text { Total Asset }}{}
\end{aligned}
$$

\section{Rasio utang terhadap aset (Debt to asset ratio)}

Rasio utang terhadap aset (Debt to asset ratio), merupakan rasio yang digunakan untuk mengukur perbandingan antara total utang dengan total aset. Dengan kata lain, rasio ini digunakan untuk mengukur seberapa besar aset perusahaan dibiayai oleh utang, atau seberapa besar utang perusahaan berpengaruh terhadap pembiayaan aset. Berikut adalah rumus yang digunakan untuk menghitung rasio utang:

$$
\text { Rasio Utang }=\frac{\text { Total Utang }}{\text { Total Aset }}
$$

\section{Persistensi Laba}

Persistensi laba merupakan revisi laba yang diharapkan dimasa yang akan datang yang diimplikasikan melalui laba tahun berjalan. Besarnya revisi ini menunjukkan tingkat persistensi laba. Laba merupakan salah satu tujuan perusahaan selain untuk dapat bertahan hidup (going concern).

Berikut adalah rumus yang digunakan untuk menghitung persistensi laba:

$P T B I_{t+1}=\frac{\text { Laba Sebelum Pajak Tahun Depan }}{\text { Rata }- \text { rata total Aset }}$

\section{Kerangka Penelitian}

$\begin{array}{lrr}\text { Berdasarkan } & \text { penelitian-penelitian } \\ \text { terdahulu, } & \text { makarane peniti }\end{array}$ 
menggambarkan kedalam kerangka penelitian berikut ini:

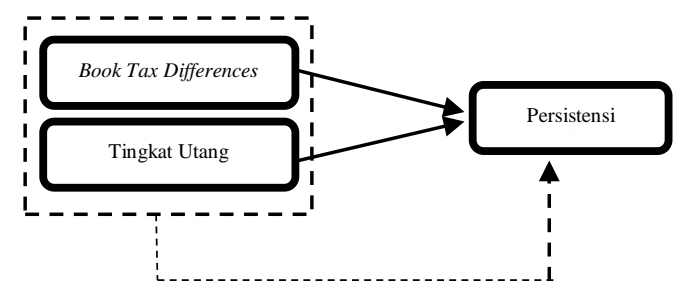

Gambar 2. Kerangka Penelitian

\section{Pengembangan Hipotesis Pengaruh Book Tax Differences terhadap Persistensi Laba}

Perbedaan Permanen dan Perbedaan Temporer digunakan dalam mengukur perbedaan laba akuntansi dan laba fiskal (Book Tax Differences). Penelitian ini dilakukan berdasarkan pendapat dalam literatur analisis keuangan yang fokus utamanya adalah book tax differences dapat digunakan Pengaruh Tingkat Utang terhadap Persistensi Laba dan untuk menilai kualitas laba akuntansi. Karena persistensi laba merupakan expected future earnings maka unsur yang mewakili dari persistensi laba tersebut yaitu Laba bersih (Net Income) (Jackson 2009).

Penelitian tentang pengaruh Book Tax Differences dengan proksi perbedaan permanen dan perbedaan temporer telah banyak dilakukan untuk mendapatan bukti empiris hubungan Book Tax Differences terhadap Persistensi Laba. Penelitian mengenai Book Tax Differences dan Persistensi Laba telah dilakukan oleh Sabrina et al. (2017), I Made Andi (2013), Praptitorini (2017), dan Barus dan Rica (2014). Dengan demikian Hipotesis yang akan diuji dalam penelitian ini adalah:

\section{H1= Book tax differences berpengaruh terhadap persistensi laba.}

\section{Pengaruh Tingkat Utang terhadap Persistensi Laba}

Subramanyam dan John, Wild (2012) menyatakan bahwa tingkat utang akan terlihat pengaruhnya terhadap laba masa depan di saat perusahaan dalam kondisi keuangan baik atau buruk, saat kondisi keuangan biasa-biasa saja maka pengaruhnya tidak dapat dibuktikan. Penelitian tentang pengaruh tingkat utang telah banyak dilakukan untuk mendapatan bukti empiris hubungan tingkat utang terhadap Persistensi Laba. Penelitian mengenai Tingkat Utang dan Persistensi Laba telah dilakukan oleh Sabrina et al. (2017), Ayu (2016) dan Fanani (2010), Namira (2018), Kasiono dan Fachrurrozie (2016). Dengan demikian Hipotesis yang akan diuji dalam penelitian ini adalah:

H2 = Tingkat utang berpengaruh terhadap persistensi laba.

\section{Pengaruh Book Tax Differences dan Tingkat Utang terhadap Persistensi Laba}

Beberapa tahun ke depan persistensi laba perusahaan satu periode kedepan diprediksi dengan informasi yang terdapat dalam book tax differences (perbedaan jumlah laba menurut perhitungan akuntansi dengan jumlah laba menurut perhitungan pajak sesuai dengan ketentuan peraturan perpajakan yang berlaku). Besarnya tingkat utang perusahaan akan menyebabkan perusahaan meningkatkan persistensi laba dengan tujuan untuk mempertahankan kinerja yang baik dimata auditor dan investor. Penelitian 
yang dilakukan oleh Sabrina et al. (2017) yang meneliti 10 perusahaan manufaktur subsektor otomotif di Bursa Efek Indonesia selama periode 2011-2015 dan menemukan hasil bahwa secara simultan book tax differences dan tingkat utang berpengaruh simultan terhadap persistensi laba. Penelitian yang sama juga dilakukan oleh Andreani Caroline Barus, Vera Rica (2014) yang meneliti 58 perusahaan manufaktur yang terdaftar di Bursa Efek Indonesia selama periode 2009-2011 menemukan hasil bahwa secara simultan, perbedaan antara laba akuntansi dengan laba fiskal (book tax differences) dan tingkat hutang berpengaruh signifikan terhadap persistensi laba. Dengan demikian Hipotesis yang akan diuji dalam penelitian ini adalah:

H3 = Book tax differences dan tingkat utang berpengaruh terhadap persistensi laba.

\section{METODE PENELITIAN}

\section{Objek, Lokasi dan Waktu Penelitian}

Objek penelitian pada Perusahaan sektor properti dan real estate yang terdaftar di Bursa Efek Indonesia tahun 2016-2018. Variabel didalam penelitian ini terdiri dari variabel independen atau variabel bebas, variabel dependen atau variabel terikat.

Tabel 1. Operasional Variabel

\begin{tabular}{|c|c|c|}
\hline Variabel & Indikator & Rumus \\
\hline $\mathrm{Y}$ & PTBI & Laba Sebelum Pajak Tahun Depan \\
\hline $\begin{array}{l}\text { Persistensi } \\
\text { Laba }\end{array}$ & $t+1$ & Rata - rata total Aset \\
\hline \multirow{2}{*}{$\begin{array}{l}\text { X1: } \\
\text { Perbedaan } \\
\text { Permanen }\end{array}$} & \multirow[t]{2}{*}{ PP } & Jumlah Perbedaan permanen dalam rekonsiliasi fiskal \\
\hline & & Total Asset \\
\hline \multirow{2}{*}{$\begin{array}{l}\text { X1: } \\
\text { Perbedaan } \\
\text { Temporer }\end{array}$} & \multirow[t]{2}{*}{ PT } & \multirow{2}{*}{$\mathrm{PT}=\frac{\text { umlah Perbeddaan Temporer dalam rekonsiliasi fiskal }}{\text { Total Asset }}$} \\
\hline & & \\
\hline $\begin{array}{l}\text { X2: } \\
\text { Tingkat } \\
\text { Utang }\end{array}$ & DAR & DAR $=\frac{\text { Total Utang }}{\text { Total Asset }}$ \\
\hline
\end{tabular}

Populasi yang digunakan dalam penelitian ini adalah 70 perusahaan sektor property dan real estate yang terdaftar di Bursa Efek Indonesia periode 2016-2018. Jumlah sampel yang dipilih dalam penelitian ini menggunakan teknik purposive sampling. Sampel dalam penelitian ini sebanyak 41 (empat puluh satu) data observasi.

Teknik analisis ini dapat digunakan untuk mengukur pengaruh lebih dari satu variabel independen terhadap variabel dependen penelitian. Model analisis regresi linier berganda digunakan untuk mengetahui pengaruh book tax differences dengan proksi perbedaan permanen dan termporer dan tingkat utang terhadap persistensi laba. Model regresi linier berganda penelitian ini ditunjukan oleh persamaan berikut:

$Y=a+\beta 1 X 1+\beta 2 X 2+\beta 3 X 3+\varepsilon$

Dimana :

$$
\begin{array}{ll}
\mathrm{Y} & =\text { Persistensi Laba } \\
\mathrm{a} & \quad \text { (konstanta) } \\
\text { konstanta } & \beta 1-\beta 3=\text { Koefisien Regresi } \\
\text { X1 } & =\text { Perbedaan Permanen } \\
\mathrm{X} 2 & =\text { Perbedaan Temporer } \\
\mathrm{X} 3 & =\text { Tingkat Utang } \\
\mathcal{E} & =\text { error }
\end{array}
$$

\section{HASIL DAN PEMBAHASAN}

\section{Analisa Statistik Deskriptif}

Tabel 2. Analisa statistik deskriptif 


\begin{tabular}{lr|r|r|r|r} 
& \multicolumn{7}{c}{ Descriptive Statistics } & \multicolumn{1}{c}{$\begin{array}{c}\text { Std. } \\
\end{array}$} \\
& $\mathrm{N}$ & Minimum & Maximum & Mean & Deviation \\
& Statistic & Statistic & Statistic & Statistic & Statistic \\
\hline PP & 41 & -.030737 & .024146 & - & .012430139 \\
& & & & .00182744 & \\
\hline PT & 41 & -.003763 & .002130 & - & .001215266 \\
\hline DAR & 41 & .041537 & .643922 & .33733766 & .202650420 \\
\hline PTBIt+1 & 41 & .001949 & .121594 & .04416159 & .030676688 \\
\hline $\begin{array}{l}\text { Valid N } \\
\text { (listwise) }\end{array}$ & 41 & & & & \\
\hline
\end{tabular}

Analisa statistik deskriptif menunjukkan nilai rata-rata dan standar deviasi masing-masing variabel yang diteliti, baik variabel bebas maupun variabel terikat, yang dihitung berdasarkan data secara keseluruhan. Book Tax Differences dengan proksi perbedaan permanen pada perusahaan property dan real estate yang menjadi sampel dalam penelitian ini berkisar antara -0,030737 yang dimiliki oleh PT. Perdana Gapura Prima Tbk tahun 2016 sampai 0,024146 yang dimiliki oleh PT. Alam Sutera Reality Tbk tahun 2016, dengan nilai rata-rata $-0,001827$, pada standar deviasi 0,012430 Nilai rata-rata lebih besar dari standar deviasi yaitu$0,001827<0,012340$. Besarnya Book Tax Differences dengan proksi perbedaan temporer pada perusahaan property dan real estate yang menjadi sampel dalam penelitian ini berkisar antara $-0,003763$ yang dimiliki oleh PT. Plaza Indonesia Realty Tbk tahun 2018 sampai 0,02130 yang dimiliki oleh PT. Lippo Cikarang Tbk tahun 2017, dengan nilai rata-rata $-0,0004473$, pada standar deviasi 0,001215266. Nilai rata-rata lebih kecil dari standar deviasi yaitu $0,0004473<0,001215266$. Book Tax Differences dengan proksi perbedaan temporer pada perusahaan property dan real estate yang menjadi sampel dalam penelitian ini berkisar antara $-0,003763$ yang dimiliki oleh PT. Plaza Indonesia Realty Tbk tahun 2018 sampai 0,02130 yang dimiliki oleh PT. Lippo Cikarang Tbk tahun 2017, dengan nilai rata-rata 0,0004473 , pada standar deviasi 0,001215266 . Nilai rata-rata lebih kecil dari standar deviasi yaitu $-0,0004473<$ 0,001215266 .

Tingkat Utang pada perusahaan property dan real estate yang menjadi sampel dalam penelitian ini berkisar antara 0,041537 yang dimiliki oleh PT. Puradelta Lestari Tbk tahun 2018 sampai 0,643922 yang dimiliki oleh PT. Alam Sutera Reality Tbk tahun 2016, mean 0,33733766 dengan nilai standar deviasi 0,202650420 . Nilai rata-rata lebih besar dari standar deviasi yaitu 0,33733766 > 0,20265420 .

Persistensi Laba pada perusahaan property dan real estate yang menjadi sampel dalam penelitian ini berkisar antara 0,001949 yang dimiliki oleh Agung Podomoro Land Tbk tahun 2018 sampai 0,121594 yang dimiliki oleh PT. Lippo Cikarang Tbk tahun 2017, mean 0,04416159 dengan nilai standar deviasi 0,030676688 . Nilai rata-rata lebih besar dari standar deviasi yaitu $0,030676688>$ 0,04416159 .

\section{Uji Normalitas}

Tabel 3. Hasil statistik uji Kolmogrov Smirnov

One-Sample Kolmogorov-Smirnov Test

Unstandardized Residual

\begin{tabular}{|c|c|c|}
\hline $\mathrm{N}$ & & 41 \\
\hline \multirow{2}{*}{$\begin{array}{l}\text { Normal } \\
\text { Parameters }{ }^{a, b}\end{array}$} & Mean & .0000000 \\
\hline & $\begin{array}{l}\text { Std. } \\
\text { Deviation }\end{array}$ & .02405502 \\
\hline \multirow{3}{*}{$\begin{array}{l}\text { Most Extreme } \\
\text { Differences }\end{array}$} & Absolute & .080 \\
\hline & Positive & .080 \\
\hline & Negative & -.075 \\
\hline
\end{tabular}




\begin{tabular}{lr}
\hline Test Statistic & .080 \\
\hline Asymp. Sig. (2-tailed) & $.200^{\mathrm{c}, \mathrm{d}}$ \\
\hline
\end{tabular}

a. Test distribution is Normal.

b. Calculated from data.

c. Lilliefors Significance Correction.

d. This is a lower bound of the true significance.

Sumber : olah data SPSS versi 25 oleh penulis(2020)

Apabila hasil signifikansi uji kolmogrov smirnov > 0,05, maka data tersebut berdistribusi normal. Berdasarkan dengan tabel diatas menunjukkan bahwa signifikansi dari uji kolmogrov smirnov sebesar 0,200. Hal ini menunjukkan bahwa $0,200>0,05(\alpha)$, sehingga dapat disimpulkan bahwa data dalam penelitian ini berdistribusi normal.

\section{Uji Multikoleniaritas}

Tabel 4. Hasil statistik uji Multikolonieritas

\begin{tabular}{|l|r|r|}
\hline \multirow{2}{*}{ Model } & \multicolumn{2}{|c|}{ Collinearity Statistics } \\
\cline { 2 - 3 } & Tolerance & \multicolumn{1}{c|}{ VIF } \\
\hline $\begin{array}{l}\text { (Constant } \\
\text { ) }\end{array}$ & & \\
\hline PP (X1) & .761 & 1.314 \\
\hline PT (X2) & .826 & 1.211 \\
\hline $\begin{array}{l}\text { DAR } \\
\text { (X3) }\end{array}$ & .784 & 1.276 \\
\hline
\end{tabular}

Sumber : olah data SPSS versi 25 oleh penulis (2020)

Berdasarkan hasil statistik uji multikolonieritas diatas menunjukkan bahwa nilai tolerance dan VIF untuk variabel Perbedaan Permanen (PP) adalah 0,761 dan 1,314; nilai tolerance dan VIF untuk variabel Perbedaan Temporer (PT) adalah 0,826 dan 1,211; dan nilai tolerance dan VIF untuk variabel Debt to Asset Ratio (DAR) adalah 0,784 dan 1,276. Sehingga seluruh variabel independen pada persamaan regresi mempunyai nilai tolerance $<1$ dan Variance inflation factor (VIF) VIF < 10. Dengan demikian dapat dikatakan tidak ada multikolinearitas, Ho diterima, artinya Tidak ada Multikolinearitas.

\section{Uji Autokorelasi}

Tabel 5. Hasil statistik Uji Autokorelasi

\begin{tabular}{|r|r|}
\hline Model & $\begin{array}{r}\text { Durbin } \\
\text { Watson }\end{array}$ \\
\hline 1 & 1.751 \\
\hline
\end{tabular}

Sumber: olah data SPSS versi 25 oleh penulis (2020)

Berdasarkan pengujian Autokorelasi menggunakan SPSS, didapatkan hasil pengujian Durbin-Watson dengan nilai $1.751(\mathrm{n}=41, \mathrm{k}=3, \mathrm{dl}=1.348 \mathrm{du}=$ 1,660) $(4$-dl $=2,652)$ dan (4-du $=2,339$. $1.751<2,339$. berada pada area tidak ada autokorelasi. Nilai Durbin-Watson yg berada pada daerah $\mathrm{du}<\mathrm{dw}<4-\mathrm{du}$ yang artinya bahwa tidak ada gejala autokorelasi dalam model regresi ini.

\section{Uji Heteroskedastisitas}

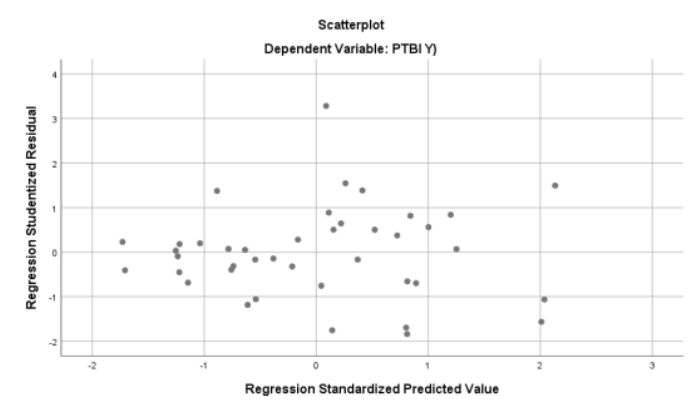

Gambar 3. Scatter plot uji heteroskedastisitas

Berdasarkan gambar scatter plot uji heteroskedastisitas dapat dilihat bahwa pola yang terbentuk menyebar di atas dan di tengah angka 0 (nol) pada sumbu Y. Dengan demikian dapat disimpulkan 
bahwa pada model regresi tidak terjadi heteroskedastisitas.

\section{Analisis Regresi Berganda}

Berdasarkan hasil pengujian statistik menggunakan analisis regresi berganda didapatkan hasil seperti dibawah ini:

Tabel 6. Hasil Statistik Analisis Regresi Berganda

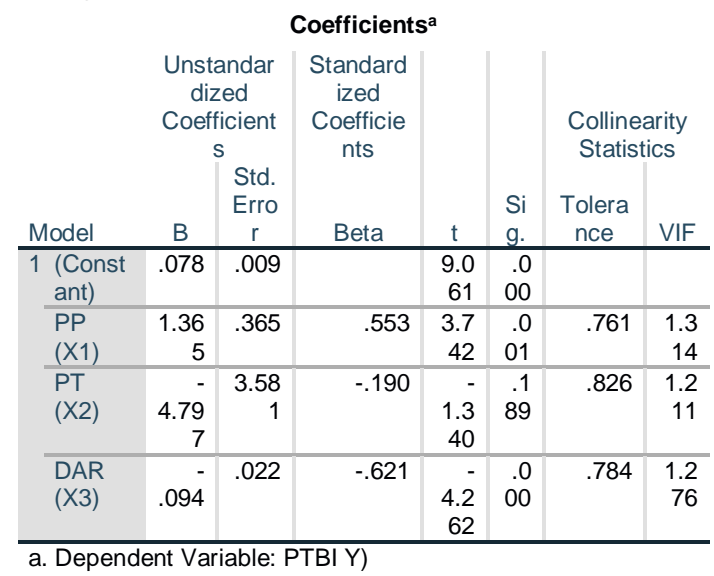

Sumber: olah data SPSS versi 25 oleh penulis (2020)

Berikut penulisan persamaan regresi berdasarkan tabel diatas dari data yang telah diolah dalam penelitian ini:

PTBI $t+1=0,078+1,365 P P-4,797 P T-$ $0,094 D A R+e$

1. Konstanta sebesar 0,078 artinya apabila nilai Book Tax Differences dan tingkat Utang sama dengan 0 (nol), maka nlai dari Persistensi Laba sebesar 0,078.

2. $\beta 1=1,365$, setiap kenaikan $1 \mathrm{x}$ Perbedaan Permanen, maka persistensi laba akan mengalami kenaikan 13,65\% dengan dugaan variabel lainnya konstan.

3. $\beta 2=4,797$, setiap kenaikan $1 \mathrm{x}$ Perbedaan Temporer, maka persistensi laba akan mengalami penurunan $47,97 \%$ dengan dugaan variabel lainnya konstan.

4. $\beta 3=0,094$, setiap kenaikan $1 \mathrm{x}$ DAR, maka persistensi laba akan mengalami penurunan $9,4 \%$ dengan dugaan variabel lainnya konstan.

\section{Uji Regresi Simultan (Uji Statistik F)}

Tabel 8. Hasil uji statistik F (Uji Simultan)

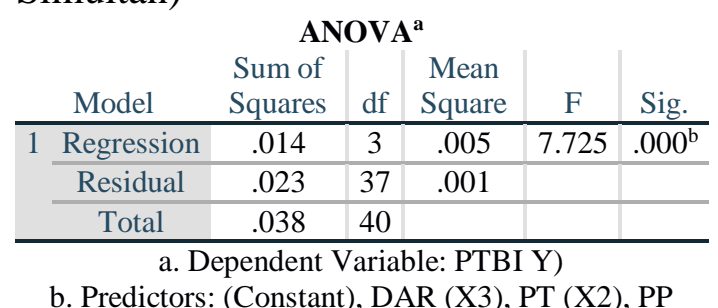
(X1)

Sumber: olah data SPSS versi 25 oleh penulis (2020)

Berdasarkan tabel diatas diperoleh $\mathrm{F}$ hitung sebesar 7,725 dan signifikansi sebesar $0.000^{\mathrm{b}}$. Nilai signifikansi lebih kecil dari 0,05, hal ini menunjukkan bahwa hipotesis diterima Book tax Differences dan Tingkat Utang dan berpengaruh secara simultan terhadap Persistensi Laba pada perusahaan sektor property dan real estate tahun 20162018.

\section{Koefisien Determinasi (R2)}

Tabel 9. Hasil Koefisien Determinasi Model Summary

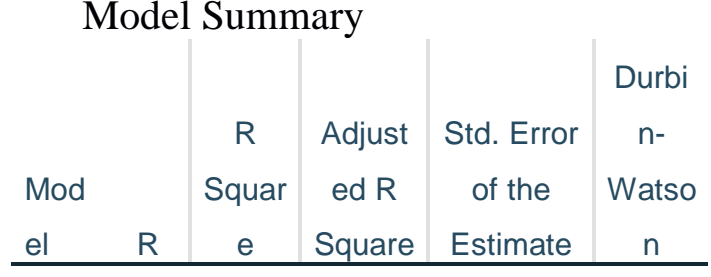




\begin{tabular}{rr|r|r|r|r}
\hline 1 & .62 & .385 & .335 & .0250112 & 1.751 \\
& $1^{\mathrm{a}}$ & & & 22 & \\
\hline
\end{tabular}

a. Predictors: (Constant), DAR (X3), PT (X2), PP $(X 1)$

b. Dependent Variable: PTBI Y)

Berdasarkan Tabel diatas diketahui nilai koefisien determinasi atau R Square adalah 0,385 . Nilai $R$ Square 0,385 ini berasal dari pengkuadratan nilai koefisien korelasi atau "R", yaitu $0,621^{\text {a }}$ $\mathrm{x} \quad 0,621^{\mathrm{a}}=0,385$ Besarnya angka koefisien determinasi (R Square) adalah 0,385 atau sama dengan 38,5\%. Angka tersebut mengandung arti bahwa variabel X1 dan X2 secara simultan (bersamasama) berpengaruh terhadap variabel Persistensi Laba (Y) sebesar 38,5\%. Sedangkan sisanya $(100 \%-38,5 \%=$ $61,5 \%$ ) dipengaruhi oleh variabel lain di luar persamaan regresi ini atau variabel lain yang tidak diteliti.

\section{Uji Regresi Parsial (Uji stastistik t)}

Uji hipotesis dengan uji t bertujuan untuk mengetahui apakah variabel independen secara simultan memiliki pengaruh yang signifikan atau tidak dengan variabel dependen.

Book Tax Differences dengan proksi perbedaan permanen sebagai variabel independen berpengaruh signifikan artinya ketika perbedaan permanen dalam rekonsiliasi fiskal semakin besar, maka persistensi laba semakin meningkat, dengan nilai koefisien 3,742 dan dengan nilai signifikansi 0,001 < 0,05, artinya terdapat pengaruh Book Tax Differences dengan proksi perbedaan permanen terhadap persistensi laba. Hasil penelitian menyatakan bahwa $\mathrm{H}_{1}$ diterima. Namun berdasarkan secara parsial adalah tidak sesuai dengan pernyataan hipotesis bahwa Book Tax Differences dengan proksi perbedaan temporer sebagai variabel independen tidak berpengaruh secara signifikan artinya ketika perbedaan temporer dalam rekonsiliasi fiskal semakin kecil, maka persistensi laba semakin menurun, dengan nilai koefisien -1,340 dan dengan nilai signifikansi $0,189>0,05$, artinya tidak terdapat pengaruh Book Tax Differences dengan proksi perbedaan temporer terhadap persistensi laba. Tingkat Utang sebagai variabel independen berpengaruh secara signifikan artinya ketika tingkat utang semakin besar, maka persistensi laba semakin meningkat, dengan nilai koefisien -4,262 dan dengan nilai signifikansi $0,000<0,05$, artinya terdapat pengaruh Tingkat Utang terhadap persistensi laba. Hasil penelitian menyatakan bahwa $\mathrm{H}_{2}$ diterima.

\section{Hasil Penelitian Dan Pembahasan}

Secara Simultan Hasil Pengaruh Book Tax Differences dan Tingkat Utang berpengaruh terhadap Persistensi Laba

Penelitian ini bertujuan untuk mengetahui pengaruh Book Tax Differences dan Tingkat Utang berpengaruh secara simultan terhadap Persistensi Laba.

Berdasarkan hasil analisis data di atas diketahui bahwa $\mathrm{F}$ hitung sebesar 7,725 dan signifikansi sebesar $0.000^{\mathrm{b}}$. Nilai signifikansi lebih kecil dari 0.05 , hal ini menunjukkan bahwa hipotesis diterima Book Tax Differences dan Tingkat Utang dan berpengaruh secara 
simultan terhadap Persistensi Laba pada perusahaan sektor property dan real estate tahun 2016-2018.

Nilai Adjusted R2 sebesar 0,385. Hal ini menunjukkan bahwa Persistensi Laba yang dipengaruhi oleh Book Tax Differences dan Tingkat Utang sebesar $38,5 \%$ sedangkan sisanya $61,5 \%$ dipengaruhi oleh variabel lain di luar penelitian ini.

\section{Secara Parsial Hasil Pengaruh Book Tax Differences dan Tingkat Utang berpengaruh terhadap Persistensi Laba}

Dari Hasil Pengujian atas pengaruh Book Tax Differences dan Tingkat Utang terhadap Persistensi Laba diperoleh persamaan sebagai berikut:

$\mathrm{Y}=\mathrm{a}+\beta 1 \mathrm{X} 1+\beta 2 \mathrm{X} 2+\beta 3 \mathrm{X} 3+\varepsilon$ $P T B I t+1=0,078+1,365 P P-4,797 P T-$ $0,094 D A R+e$

Book Tax Differences dengan proksi perbedaan permanen berpengaruh secara positif terhadap Persistensi Laba pada perusahaan sektor property dan real estate tahun 2016-2018, Hasil analisis data hipotesis pertama diketahui bahwa nilai t hitung 3,742 dan dengan nilai signifikansi $0,001<0,05$. Sehingga dapat disimpulkan bahwa Book Tax Differences dengan proksi perbedaan permanen berpengaruh signifikan terhadap Persistensi Laba.

1. Book Tax Differences dengan proksi perbedaan temporer berpengaruh negatif terhadap Persistensi Laba pada perusahaan sektor property dan real estate tahun 2016-2018, Hasil analisis data hipotesis pertama diketahui bahwa nilai t hitung $-1,340$ dan dengan nilai signifikansi 0,189 $>0,05$. Sehingga dapat disimpulkan bahwa Book Tax Differences dengan proksi perbedaan temporer tidak berpengaruh signifikan terhadap Persistensi Laba.

2. Tingkat Utang berpengaruh negatif terhadap Persistensi Laba pada perusahaan sektor property dan real estate tahun 2016-2018, Hasil analisis data hipotesis pertama diketahui bahwa nilai t hitung $-4,262$ dan dengan nilai signifikansi 0,000 $<0,05$. Sehingga dapat disimpulkan bahwa Tingkat Utang dengan berpengaruh signifikan terhadap Persistensi Laba.

\section{KESIMPULAN DAN SARAN}

\section{Kesimpulan}

1. Berdasarkan hipotesis pertama, Book Tax Differences dengan proksi Perbedaan Permanen berpengaruh terhadap Persistensi Laba. Hal ini terjadi karena perbedaan permanen lebih banyak mencakup beban yang tidak diperkenankan menurut pajak seperti biaya jamuan tamu, sumbangan, natura, pendapatan bunga, bunga atau deviden maka laba menurut akuntansi akan lebih kecil dari pada laba menurut pajak. Karena Hipotesa $\left(\mathrm{H}_{1}\right)$ diterima, maka Book Tax Differences dengan proksi perbedaan permanen dapat digunakan untuk menganalisa Persistensi Laba pada perusahaan Sektor Property dan Real Estate yang terdaftar di Bursa Efek Indonesia tahun 2016-2018.

2. Berdasarkan hipotesis pertama, Book Tax Differences dengan proksi 
Perbedaan Temporer tidak berpengaruh terhadap Persistensi Laba. Hal ini berarti tinggi atau rendahnya perbedaan temporer tidak merubah variasi nilai persistensi laba. Hal ini terjadi karena pada perbedaan temporer terdapat item berupa aset pajak tangguhan, kewajiban pajak tangguhan, penghasilan beban pajak tangguhan dan beban pajak tangguhan yang akan memengaruhi neraca dan laba rugi. Karena Hipotesa $\left(\mathrm{H}_{1}\right)$ ditolak, maka Book Tax Differences dengan proksi perbedaan temporer tidak dapat digunakan untuk menganalisa Persistensi Laba pada perusahaan Sektor Property dan Real Estate yang terdaftar di Bursa Efek Indonesia tahun 2016-2018.

3. Berdasarkan hipotesis kedua, Tingkat Utang berpengaruh terhadap Persistensi Laba. Hal ini berarti besarnya tingkat utang perusahaan akan menyebabkan perusahaan meningkatkan persistensi laba dengan tujuan untuk mempertahankan kinerja yang baik di mata investor dan auditor. Karena Hipotesa $\left(\mathrm{H}_{2}\right)$ diterima, maka Tingkat Utang dapat digunakan untuk menganalisa Persistensi Laba pada perusahaan Sektor Property dan Real Estate yang terdaftar di Bursa Efek Indonesia tahun 20162018.

4. Berdasarkan hipotesis ketiga, Book Tax Differences dan Tingkat Utang berpengaruh secara simultan terhadap Persistensi Laba. Hal ini berarti Book Tax Differences dapat digunakan untuk menilai kualitas laba akuntansi. Persistensi laba perusahaan satu periode kedepan dapat diprediksi dengan informasi yang terdapat dalam book tax differences (perbedaan jumlah laba menurut perhitungan akuntansi dengan jumlah laba menurut perhitungan pajak sesuai dengan ketentuan peraturan perpajakan yang berlaku). Karena Hipotesa (H3) diterima, maka Book Tax Differences dan Tingkat Utang dapat digunakan untuk menganalisa Persistensi Laba pada perusahaan Sektor Property dan Real Estate yang terdaftar di Bursa Efek Indonesia tahun 2016-2018.

\section{SARAN}

1. Sehubungan dengan terbatasnya jumlahvariabel independen dalam penelitian ini. Untuk itu kepada peneliti dalam melakukan penelitian lanjutan mengenai Persistensi Laba ini. Lebih menambah variabel independen lain yang dapat mempengaruhi persistensi laba agar dapat menjadi bahan pertimbangan bagi perusahaan dalam mengambil keputusan dan dapat ditarik generalisasinya.

2. Penelitian mengenai Persistensi Laba memberikan bukti adanya pengaruh dari variabel Book Tax Differences dan Tingkat Utang terhadap khususnya pada perusahaan sektor property dan real estate yang terdaftar di Bursa Efek Indonesia tahun 2016-2018. Untuk itu kepada pembaca dapat mengembangkan penelitian ini dan menambah objek dari berbagai sektor agar dapat memberikan referensi kepada investor, calon investor, dan pengguna lain untuk pengambilan keputusan investasi yang lebih baik. 
3. Penelitian mengenai Persistensi Laba memberikan bukti adanya pengaruh dari variabel Book Tax Differences dan Tingkat Utang terhadap khususnya pada perusahaan sektor property dan real estate yang terdaftar di Bursa Efek Indonesia tahun 2016-2018. Untuk itu kepada perusahaan penelitian ini dapat mejadi bahan pertimbangan perusahaan untuk lebih memaksimalkan dan mempertahankan laba perusahaan ditahun selanjutnya agar perusahaan memiliki laba yang berkualitas sehingga memiliki persistensi laba yang sustainable (laba yang mempunyai kualitas tinggi).

\section{DAFTAR PUSTAKA}

Atwood, T.J, M. S. D. and L. A. M. (2010). Book-tax conformity, earnings persistences and the association between earnings and future cash flows. Journal of Accounting and Economics, 50, 111-125.

Bandi. (2009). Kualitas Laba dalam Perspektif Akrual - Arus Kas dan Pensinyalan Dividen. Disertasi Program Doktor Universitas Diponegoro, Semarang.

Barus, A. C., \& Rica, V. (2014). Analisis Faktor-Faktor Yang Mempengaruhi Persistensi Laba Pada Perusahaan Manufaktur Di Bursa Efek Indonesia. Jurnal Wira Ekonomi Mikroskil, 4(02), 71-80.

Blaylock Bradley, Terry Shevlin, and R. J. W. (2012). Tax Avoidance, Large Positive Temporary Book Tax Differences and Earnings Persistence. American Accounting
Association, 87 no 1, 91-120.

Fanani, Z. (2010). Analisis FaktorFaktor Penentu Persistensi Laba. Jurnal Akuntansi Dan Keuangan Indonesia, 7(1).

Ghozali, I. (2011). Aplikasi Analisis Multivariate dengan program IBM SPSS 19 (Edisi 5). Semarang: Badan Penerbit Universitas DIponegoro.

Ghozali, I. (2018). Aplikasi Analisis Multivariate dengan program IBM SPSS 25 (Edisi 9). Semarang: Badan Penerbit Universitas Diponegoro.

Gujarati, D. N. (2003). Basic Econometrics. 4th ed. Singapore: Mc-Graw Hill.

Hanlon, M. (2005). The Persistence and Pricing of Earnings, Accruals, and Cash Flows When Firms Have Large Book-tax Differences. The Accounting Review, 80(1), 137-166.

Harahap, S. S. (2009). Analisa Kritis atas Laporan Keuangan. Jakarta: Raja Grafindo Persada.

Hery, S.E, M. S. R. C. (2015). Pengantar Akuntansi (Comprehens). Jakarta: Grasindo.

IAI. (2009). Akuntansi Pajak Penghasilan (revisi 2009). In PSAK No. 46. Jakarta: Salemba Empat.

Jackson, M. (2009). Book Tax Differences and Earnings Growth.

Working Paper. University of Oregon.

Kasiono, D. dan F. (2016). Determinan Persistensi Laba pada Perusahaan Manufaktur yang terdaftar di BEI. Accounting Analysis Journal, 5(1).

Madiarsmo. (2016). Perpajakkan. Yogyakarta: Andi.

Maqfiroh Catur Sari, and K. (2018). The Influence of Book Tax Differences, Operating Cash Flow, Leverage and Firm Size towards Earnings Persistence. Accounting Analysis 
Journal, 7 no 3, 151-158.

Martinez Antonio Lopo, Tatiana Bossonello Tolentino de Souza, D. S. M. (2016). Book Tax Differences, Earnings Persistence and Tax Planning Before and After the Adoption of IFRS in Brazil. Advances in Scientific and Applied Accounting, 9 no 2.

Moienadin, M. (2014). Examining the Earnings Persistence and Its Components in Explaining the Future Profitability. Journal of Contemporary Research In Business, 5 no 10.

Munawir. (2004). Analisa Laporan Keuangan. Yogyakarta: Liberty.

Nadya, Namira Fitri, dan D. Z. (2018). Analisis Faktor-Faktor Penentu Persistensi Laba (studi empiris pada perusahaan Properti dan Real Estate yang terdaftar di Bursa Efek Indonesia periode 2012-2016). Jurnal AKRAB JUARA, Volume $3 \mathrm{~N}$, (157-169).

Pagalung, G. (2006). Kualitas Laba : Faktor - Faktor Penentu dan Konsekuensi Ekonominya. Disertasi. Universitas Gajah Mada. Yogyakarta.

Penman Stephen H. and Xiao- Jun Zhang. (2002). Accounting Conservatism, the Quality of Earnings, and Stock Returns. The Accounting Review, 77(2), 237-264.

Persada dan martani. (2010). ANALISIS FAKTOR YANG MEMPENGARUHI BOOK TAX GAP DAN PENGARUHNYA TERHADAP PERSISTENSI LABA. Jurnal Akuntansi Dan Keuangan Indonesia, 7(2), 205-221. Poernomo, Y. (2008). Modul Tidak Dipublikasikan. In Modul Akuntansi Perpajakan. Badan Pelatihan dan
Pendidikan Keuangan.

Pohan, C. A. (2014). Perpajakan Indonesia. Jakarta: Mitra Wacana Media.

Praptitorini, Mirna Dyah. (2017). Analisis Pengaruh Permanent Differences, Temporary Differences, LPBTD, LNBTD, dan Tingkat Hutang terhadap Persistensi Laba. Jurnal Ilmu Manajemen Dan Akuntansi Terapan (J'MAT), Volume $8 \mathrm{~N}$.

Putri, A.A Ayu Ganitri, dan N. luh S. (2016). Pengaruh tingkat hutang dan Kepemilikan Manajerial terhadap persistensi Laba pada Perusahaan Manufaktur. E-Jurnal Akuntansi Universitas Udayana, Vol.15.2., 915-942.

Putri, Sabrina Anindita Putri, Khairunnisa, dan K. S. A. M. (2017). Pengaruh Aliran Kas Operasi, Book Tax Differences, dan Tingkat Utang terhadap Persistensi Laba(Studi pada Perusahaan Manufaktur Subsektor Otomotif yang Terdaftar di Bursa Efek Indonesia Tahun 2011 - 2015. ..EProceeding of Management, 4(1), 14.

Putri, A. S. (2017). Pengaruh aliran kas operasi, book tax dfferences, dan tingkat hutang terhadap persistensi laba. Jurnal Riset Akuntansi Kontemporer (JRAK), Vol 9.1 Ap, 20-35.

Salsabiila, Azzahra, Dudi Pratomo, dan A. N. (2016). Pengaruh Book Tax Differences dan Aliran Kas Operasi terhadap Persistensi Laba. Jurnal Akuntansi, Volume XX, 314-329.

Scot, W. (2014). Financial Accounting Theory. Canada: Pearson.

Sekaran, U. (2006). Research Methods for Business. New York: John Wiley 
and Sons.

Sekaran, U. (2013). Metodologi Penelitian untuk Bisnis. Jakarta: Salemba Empat.

Septavita, N. (2016). Pengaruh BookTax Differences, Arus Kas Operasi, Tingkat Hutang, dan Ukuran Perusahaan pada Persistensi Laba. JOM Fekon, Vol.3, No.

Subramanyam., \& J. J. W. (2012). Analisis Laporan Keuangan (Edisi 10,). Jakarta: Salemba Empat.

Subramanyam, K. R. (2017a). Analisis Laporan Keuangan. Jakarta: Salemba Empat.

Subramanyam, K. R. (2017). Analisis Laporan Keuangan (Edisi 11 B). Jakarta: Salemba Empat.

Sugiyono. (2010). Metode Penelitian Bisnis. Bandung: Alfabeta.

Suwandika, I. M. A. dan I. B. P. A. (2013). Pengaruh Perbedaan Laba Akuntansi, Laba Fiskal, Tingkat Hutang Pada Persistensi Laba. EJurnal Akuntansi Universitas Udayana, 5.1, 196-214.

Suwardjono. (2005). Teori Akuntansi. In Perekayasaan Pelaporan Keuangan: Vol. Edisi Keti. Yogyakarta: BPFE.
Tanya YH Tang, \& M. F. (2012). Earnings Presistence and Stock Market Reactions to Different Information in Book-Tax Differences : Evidence from China. The Internasional Journal of Accounting, 47, 369-397.

Widiatmoko Jacobus, and M. . K. I. (2019). Book Tax Differences, Operating Cash Flow, Leverage and Earning Persistence in Indonesia Manufacturing Companies. JURNAL DINAMIKA AKUNTANSI, 11 No 2, 151-159.

Wild, Subramanyam dan Robert Wild, S. dan R. (2014). Analisis Laporan Keuangan (Buku 2 edi). Salemba Empat.

Zain, M. (2008). Manajemen Perpajakan. Jakarta: Salemba Empat.

Zhou, M. (2016). Does Accounting For Uncertain Tax Benefits Provide Information About The Relation Between Book-Tax Differences and Earnings Persistence?. Review of Accounting and Finance, 15(1), 6584. 
ISSN : $2406-7415$

e-ISSN : $2655-9919$

JURNAL AKUNTANSI DAN BISNIS KRISNADWIPAYANA

DOI: http://dx.doi.org/10.35137/jabk.v7i3.444 Vol. 7 No. 3 (September - Desember) 2020

Copyright (c) 2020 Mishelei Loen, SE., M.Si., Jessica Putri Diharjo 
ISSN : $2406-7415$

e-ISSN : $2655-9919$

JURNAL AKUNTANSI DAN BISNIS KRISNADWIPAYANA

DOI: http://dx.doi.org/10.35137/jabk.v7i3.444 Vol. 7 No. 3 (September - Desember) 2020 